\title{
ACMG practice guideline: Genetic evaluation of short stature
}

\author{
Laurie H. Seaver, $M D^{1,2}$, and Mira Irons, $M D^{3}$, on behalf of the American College of Medical Genetics \\ (ACMG) Professional Practice and Guidelines Committee
}

\begin{abstract}
Disclaimer: This guideline is designed primarily as an educational resource for health care providers to help them provide quality medical genetic services. Adherence to this guideline does not necessarily assure a successful medical outcome. This guideline should not be considered inclusive of all proper procedures and tests or exclusive of other procedures and tests that are reasonably directed to obtaining the same results. In determining the propriety of any specific procedure or test, the geneticist should apply his or her own professional judgment to the specific clinical circumstances presented by the individual patient or specimen. It may be prudent, however, to document in the patient's record the rationale for any significant deviation from this guideline.
\end{abstract}

\begin{abstract}
Short stature is a common indication for genetic evaluation. The differential diagnosis is broad and includes both pathologic causes of short stature and nonpathologic causes. The purpose of genetic evaluation for short stature is to provide accurate diagnosis for medical management and to provide prognosis and recurrence risk counseling for the patient and family. There is no evidence-based data to guide the geneticist in an efficient, cost-effective approach to the evaluation of a patient with short stature. This guideline provides a rubric for the evaluation of short stature evaluation and summarizes common diagnoses and clinical testing available. Genet Med 2009:11(6):465-470.
\end{abstract}

Key Words: short stature, skeletal dysplasia, intrauterine growth restriction

\section{OBJECTIVE}

To provide guidance for medical geneticists and other physicians regarding genetic evaluation of pathologic short stature.

\section{BACKGROUND INFORMATION}

Short stature is a common reason for referral for pediatric subspecialty evaluation. The purpose of genetic evaluation of short stature is to provide an accurate diagnosis and to provide information to the patient and family regarding natural history, prognosis, available treatment, genetic basis, and recurrence risk.

Potential diagnoses include familial short stature, constitutional delay of growth, occult pulmonary, renal or gastrointes-

From the ${ }^{1}$ Kapi ${ }^{6}$ olani Medical Specialists, ${ }^{2}$ Department of Pediatrics, John A. Burns School of Medicine, Honolulu, Hawaii; and ${ }^{3}$ Division of Genetics, Department of Pediatrics, Children's Hospital Boston, Harvard Medical School, Boston, Massachusetts.

Laurie H. Seaver, MD, Hawaii Community Genetics, 1441 Kapiolani Blvd., Suite 1800, Honolulu, HI 96813. E-mail: laurie.seaver@kapiolani.org

Disclosure: The authors declare no conflict of interest.

Submitted for publication March 18, 2009.

Accepted for publication March 18, 2009.

Published online ahead of print May 14, 2009.

DOI: $10.1097 /$ GIM.0b013e3181a7e8f8 tinal disease, endocrinopathies, and genetic disorders. These categories are not mutually exclusive, and the molecular basis of many causes of short stature has already been, and continues to be, elucidated. Depending on the availability of the various subspecialists in the geographic area and the presence or absence of associated physical or developmental concerns, the medical geneticist may be one of the first to evaluate an individual with a primary indication of short stature or may be asked to provide consultation regarding genetic testing once a diagnosis is made by other physicians. If the medical geneticist is the primary consultant in the evaluation of an individual with short stature, then he or she must be familiar with the common nonpathologic conditions associated with short stature in addition to the teratogenic and genetic causes. One study reported 353 patients referred for genetic evaluation with the primary indication of short stature (defined as height $<3$ rd centile). Almost $50 \%$ of the patients were considered to have either constitutional delay of growth or familial short stature. The most common pathologic diagnosis was chromosome abnormality (19\%), primarily Turner syndrome, and its variants. In $3 \%$ of cases, a diagnosis of a recognized multiple malformation syndrome was made, and in almost $2 \%$ a previously unrecognized endocrine cause was identified. ${ }^{1}$

The majority of information and guidelines for evaluation of individuals, usually children, with short stature comes from the pediatric endocrinology literature, particularly addressing evaluation for growth hormone deficiency and indications for growth hormone therapy. Although there are a multitude of publications regarding identification of genes associated with growth and gene defects associated with short stature, there is a paucity of information directed toward the medical geneticist's approach to short stature and appropriate genetic testing. The most recent publication that specifically addressed the diagnostic approach to genetic causes of short stature was issued more than 20 years ago. ${ }^{2}$ More recently, Kant et al. ${ }^{3}$ suggested an algorithm for the molecular diagnosis of short stature, although syndromes that may present with only minor anomalies were not included. There is currently no evidence-based literature to support the diagnostic evaluation of short stature by the medical geneticist. 
This guideline will assume that nonpathologic familial short stature, constitutional delay of growth, hypothyroidism, and occult disease have been ruled out as a cause for short stature. This guideline is also meant to apply to patients who might present for genetic evaluation with the chief concern of short stature, although minor anomalies and some major anomalies may be identified. It is not intended to include all genetic conditions for which short stature may be a feature. Selected inborn errors of metabolism are included if they are associated with other physical features or skeletal changes. A brief review of nonpathologic causes of short stature is included. A diagnostic algorithm is presented along with information regarding availability and utility of molecular testing for specific genes associated with short stature and intrauterine growth restriction (IUGR).

\section{ANALYSIS OF GROWTH AND PERTINENT HISTORICAL INFORMATION}

The first assessment that must be made when a child presents with short stature is whether a pathologic diagnosis is likely to be present. There are several factors that one must consider in the evaluation of short stature, including genetic potential for growth, rate of growth, and pattern of growth. The definition most commonly used for short stature is height-for-age less than two standard deviations below average for gender, which is demonstrated on the standard growth curves as a length or height less than the 3rd centile. Standard growth curves used in the United States are based on a North American population; these curves may not apply to all racial and ethnic groups, for which specific growth curves may or may not be available.

The single most common useful indicator, in addition to the absolute height, is growth velocity. Growth velocity is ideally assessed by reviewing previous growth points or by remeasurement over a 4-6 month interval. Crossing of several centile lines between 3 years of age and late childhood or early adolescence suggests a pathologic diagnosis. Healthy large infants, however, often cross centiles in the first 3 years of life and establish a new growth curve more appropriate for their genetic potential. ${ }^{4}$ Genetic potential or target height is estimated for boys by calculating the (father's height [cm]) + (mother's height $[\mathrm{cm}]+13) / 2$ and for girls (father's height $[\mathrm{cm}])+$ (mother's height $[\mathrm{cm}]-13) / 2$. Most children will reach an adult height within $10 \mathrm{~cm}$ of the target height. The centile for this target height at age 18 years can be helpful to determine if the child is likely, at his or her present height and age, to reach that potential.

Analysis of other growth parameters, including weight and head circumference, are also important in the overall analysis of a child's growth pattern. In many pathologic types of short stature, weight is affected first, then height velocity, and finally brain growth (documented by head circumference). Low weight for height is more likely due to nutritional deficiency, chronic or occult disease, or other pathologic conditions. Children with endocrine disorders often have short stature with normal weight for height, or even relative obesity. ${ }^{4}$ Bone age, as a measure of skeletal maturity, can also be useful, although a delayed bone age ( $<2$ standard deviations compared to the chronologic age) is nonspecific and associated with many different causes of short stature. Finally, analysis of body proportions, such as arm span-to-height ratio and upper to lower segment ratio are also helpful in documenting disproportionate short stature.

Another key component of the evaluation is the time of onset of short stature. The small for gestational age (SGA) infant presents a special challenge for the medical geneticist. In this case, detailed information regarding familial birth measurements and growth pattern, maternal stature, parity, presence of more than one fetus, potential teratogenic exposures, onset of growth deficiency, placental function, amniotic fluid volume, and the presence or absence of structural anomalies are crucial to the assessment and evaluation. Restriction in fetal growth in the later stages of pregnancy is suggestive of placental insufficiency. Maternal health and surgical history are important to determine potential contribution to fetal growth restriction (e.g., maternal vascular disease, history of gastric bypass, or other surgery that could lead to maternal nutritional deficiency). Pathologic examination of the placenta can yield important clues to factors contributing to deficient fetal growth.

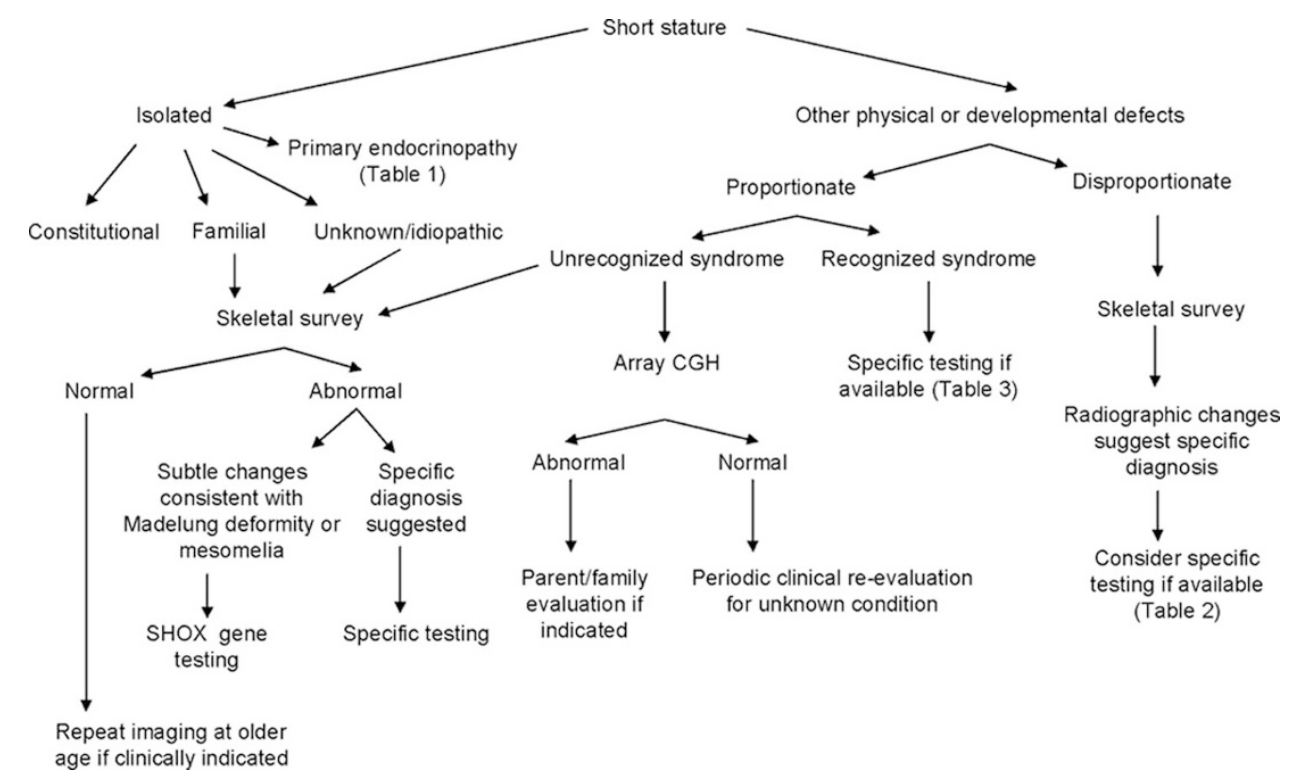

Fig. 1. Diagnostic algorithm for genetic evaluation of short stature. 
The classic definition of IUGR or SGA is a fetus or infant whose length and weight are less than the 10th centile for the gestational age. By definition, then, up to $10 \%$ of normal infants could be classified as SGA. A common alternative definition is similar to that for postnatal onset of short stature: two standard deviations below the average for the gestational age and sex. Using this latter definition would likely lead to a higher proportion of infants with true pathologic growth deficiency. Depending on the cause, duration, and severity of the IUGR, the infant may or may not exhibit "catch up" growth. This "catch up" growth in otherwise healthy infants is usually complete by 2 years of age. ${ }^{5}$

Knowledge of familial growth patterns is also important in the evaluation of the infant or child with short stature. Constitutional delay of growth is suggested by deceleration of length/ height in the first 3 years of life, a normal or near-normal height velocity during childhood (4-7 cm/year), delayed bone age and pubertal development, and final adult height within the normal range. Constitutional delay of growth can be familial; careful questioning of the parents about their childhood growth patterns and onset of puberty can be helpful. Familial short stature can be characterized by early deceleration in linear growth depending on the infant's birth measurements, a normal or near-normal growth velocity in childhood, normal bone age and pubertal development, and height as an adult that is short, but appropriate for the target height.

\section{PATHOLOGIC SHORT STATURE}

A diagnostic approach to pathologic short stature is presented in Figure 1. This approach first requires that one differentiates between isolated short stature and short stature that is associated with other physical and/or developmental abnormalities. If the child falls within the latter group, the physician must then differentiate between proportionate and disproportionate short stature. A careful physical examination with measurements is necessary to determine whether there is a disproportionate body habitus.

The differential diagnosis of isolated short stature includes nonpathologic and pathologic familial short stature, constitutional growth delay (as discussed earlier), a primary endocrinopathy (Table 1), short stature in girls with $\mathrm{X}$ chromosome abnormalities (i.e., Turner syndrome or its variants), or short stature secondary to mutations in the SHOX gene. Although most SHOX gene mutations result in characteristic skeletal changes (Madelung deformity and mesomelia), mutations have also been identified in familial and simplex cases of idiopathic short stature. ${ }^{6}$ The skeletal changes of dyschondrosteosis may not be apparent until late childhood or pubertal age and are less commonly noted in males. ${ }^{6}$ The reported frequency of SHOX gene mutations in children with idiopathic short stature has varied from $1.1 \%$ to $12.5 \%$ depending on selection criteria and testing methodology. ${ }^{7}$ For this reason, skeletal survey should be considered in some cases of familial short stature to look for subtle changes that might be diagnostic. If there are any clinical or radiographic findings suggestive of dyschondrosteosis, SHOX gene testing could be considered. Skeletal survey should also be considered in cases with significant short stature $(>3$ standard deviations) if no other diagnosis is apparent.

Review of the clinical, developmental, and family histories and a detailed physical examination are required to document the presence of major and/or minor malformations, degree of developmental delay if present, and other features that would suggest an underlying chromosome abnormality or recognizable syndrome.
If physical examination reveals disproportionate short stature, a skeletal survey (Table 2) is recommended to look for evidence of a skeletal dysplasia. Molecular genetic testing is available for confirmation of some of these conditions (Table 3). In some of the more mild skeletal dysplasias, a skeletal survey performed in the first years of life may not be diagnostic, and periodic clinical and radiographic reevaluation is necessary. In other disorders, e.g., chondrodysplasia punctata, the characteristic features may be missed by taking the radiographs too late.

\begin{tabular}{|c|c|c|c|}
\hline $\begin{array}{l}\text { Short stature } \\
\text { with endocrinopathy }\end{array}$ & Gene & Technique & Inheritance \\
\hline \multirow{2}{*}{$\begin{array}{l}\text { Combined pituitary } \\
\text { deficiency (CPD) }\end{array}$} & PROP1 & $\mathrm{S}, \mathrm{TM}$ & $\mathrm{AR}$ \\
\hline & $\begin{array}{l}\text { POU1F1 } \\
\quad(\text { PITX1) }\end{array}$ & S & $\mathrm{AD}, \mathrm{AR}$ \\
\hline $\begin{array}{l}\text { CPD/septooptic } \\
\text { dysplasia }\end{array}$ & $H E S X 1$ & S & $\mathrm{AD}, \mathrm{AR}, \mathrm{Sp}$ \\
\hline $\begin{array}{l}\text { CPD II (Laron } \\
\text { syndrome) }\end{array}$ & GHR & S & $\mathrm{AR}$ \\
\hline $\begin{array}{l}\text { CPD III/rigid } \\
\text { cervical spine }\end{array}$ & $L H X 3$ & S & $\mathrm{AR}$ \\
\hline $\begin{array}{l}\text { Growth hormone } \\
\text { deficiency }+ \text { mental } \\
\text { retardation }\end{array}$ & $S O X 3$ & FISH, Arr & XLR \\
\hline $\begin{array}{l}\text { Hypopituitarism, } \\
\text { X-linked }\end{array}$ & $S O X 3$ & Arr & XLR \\
\hline $\begin{array}{l}\text { Insulin-like growth } \\
\text { factor } 1 \text { deficiency }\end{array}$ & $I G F 1^{a}$ & & $\mathrm{AR}$ \\
\hline $\begin{array}{l}\text { Insulin-like growth } \\
\text { factor } 1 \text { resistance }\end{array}$ & $I G F 1 R^{a}$ & & $\mathrm{AD}, \mathrm{AR}$ \\
\hline $\begin{array}{l}\text { Isolated growth hormone } \\
\text { deficiency type } \\
{\mathrm{IA}, \mathrm{IB}^{a}}\end{array}$ & $G H 1^{a}$ & & $\mathrm{AR}$ \\
\hline $\begin{array}{l}\text { Isolated growth hormone } \\
\text { deficiency type } \mathrm{II}^{a}\end{array}$ & $G H 1^{a}$ & & $\mathrm{AD}$ \\
\hline $\begin{array}{l}\text { Thyroid hormone } \\
\text { resistance }\end{array}$ & THRB & S & $\mathrm{AD}, \mathrm{AR}$ \\
\hline
\end{tabular}

${ }^{a}$ Testing not available in the United States at the time of manuscript preparation. $\mathrm{AD}$, autosomal dominant; AR, autosomal recessive; Arr, array comparative genomic hybridization; FISH, fluorescence in situ hybridization; S, gene sequencing; TM, targeted mutation analysis.

Table 2. Dysmorphology skeletal survey

AP and lateral views of skull

AP and lateral views of entire spine

AP chest with rib views

AP pelvis

AP long bones

AP hands

AP feet

Lateral ankle and knee 
Table 3. Selected skeletal dysplasias/dysostoses

\begin{tabular}{|c|c|c|c|}
\hline Selected skeletal dysplasias/dysostoses & Gene & Technique & Inheritance \\
\hline Achondroplasia & $F G F R 3$ & $\mathrm{TM}$ & $\mathrm{AD}$ \\
\hline Albright hereditary osteodystrophy & $G N A S$ & $\mathrm{~S}$ & $\mathrm{AD}$ \\
\hline Cartilage hair hypoplasia & $R M R P$ & $\mathrm{~S}$ & $\mathrm{AR}$ \\
\hline \multicolumn{4}{|l|}{ Chondrodysplasia punctata } \\
\hline $\mathrm{X}$-linked recessive & ARSE & A, S, Dup, Del & XLR \\
\hline Rhizomelic, type 1 & PEX7 & A & $\mathrm{AR}$ \\
\hline Rhizomelic, type 2 & GNPAT, AGPS & $\mathrm{A}, \mathrm{E}$ & $\mathrm{AR}$ \\
\hline X-linked dominant, Conradi-Hunermann & $E B P$ & $\mathrm{~A}, \mathrm{~S}$ & XLD \\
\hline Cleidocranial dysplasia & $R U N X 2$ & $\mathrm{~S}$, Arr & $\mathrm{AD}$ \\
\hline Diastrophic dysplasia & $S L C 26 A 2$ & $\mathrm{~S}$ & $\mathrm{AR}$ \\
\hline Hereditary multiple exostoses & EXT1, EXT2 & $\mathrm{S}$ & $\mathrm{AD}$ \\
\hline Hypochondroplasia & $F G F R 3$ & $\mathrm{TM}$ & $\mathrm{AD}$ \\
\hline Hypophosphatasia & $A L P L$ & A, S & $\mathrm{AD}, \mathrm{AR}$ \\
\hline \multicolumn{4}{|l|}{ Hypophosphatemic rickets } \\
\hline $\mathrm{X}$-linked dominant & PHEX & S, Dup, Del & XLD \\
\hline Autosomal dominant & $F G F 23$ & $\mathrm{~S}$ & $\mathrm{AD}$ \\
\hline Kniest dysplasia & COL2A1 & $\mathrm{S}$ & $\mathrm{AD}$ \\
\hline Langer mesomelic dwarfism & SHOX & $\mathrm{S}$, Arr & $\mathrm{AR}$ \\
\hline Leri-Weill dyschondrosteosis & SHOX & $\mathrm{S}$, Arr & XLD \\
\hline \multirow[t]{2}{*}{ Multiple epiphyseal dysplasia } & COL9A1, COL9A2, COL3, COMP, MATN3 & $\mathrm{S}$ & $\mathrm{AD}$ \\
\hline & DTDST & & AR \\
\hline \multicolumn{4}{|l|}{ Mucopolysaccharidoses } \\
\hline Type $1 \mathrm{H}, 1 \mathrm{~S}, 1 \mathrm{H} / \mathrm{S}$ & $I D U A$ & $\mathrm{~A}, \mathrm{E}$ & AR \\
\hline Type II & $I D S$ & $\mathrm{~A}, \mathrm{E}, \mathrm{S}$ & XLR \\
\hline Types IVA and IVB & GALNS, GLB1 & $\mathrm{A}, \mathrm{E}$ & $\mathrm{AR}$ \\
\hline Type VI & $A R S B$ & $\mathrm{~A}, \mathrm{E}$ & $\mathrm{AR}$ \\
\hline Type VII & $S U S B$ & $\mathrm{~A}, \mathrm{E}$ & $\mathrm{AR}$ \\
\hline \multicolumn{4}{|l|}{ Osteogenesis imperfecta } \\
\hline Type 1 & COL1A1, COL1A2 & $\mathrm{S}, \mathrm{B}$ & $\mathrm{AD}$ \\
\hline Type 3 & COL1A1, COL1A2 & $\mathrm{S}, \mathrm{B}$ & $\mathrm{AD}$ \\
\hline Type 4 & COL1A1, COL1A2 & $\mathrm{S}, \mathrm{B}$ & $\mathrm{AD}$ \\
\hline Type 7 & CRTAP & $\mathrm{S}$ & $\mathrm{AR}$ \\
\hline Type 8 & LEPRE1 & $\mathrm{S}$ & $\mathrm{AR}$ \\
\hline Pseudoachondroplasia & COMP & $\mathrm{S}$ & $\mathrm{AD}$ \\
\hline Pycnodysostosis & $C T S K^{a}$ & & $\mathrm{AR}$ \\
\hline Schmid metaphyseal dysplasia & COL10A1 & $\mathrm{S}$ & $\mathrm{AD}$ \\
\hline Schwartz-Jampel & $H S P G 2^{a}, \operatorname{LIFR}^{a}$ & & $\mathrm{AR}$ \\
\hline Spondyloepiphyseal dysplasia (congenita, tarda) & COL2A1 & $\mathrm{S}$ & $\mathrm{AD}$ \\
\hline Spondylepiphyseal dysplasia tarda, X-linked & $S E D L$ & $\mathrm{~S}$ & XLR \\
\hline Spondylocarpotarsal synostosis & $F L N B$ & $\mathrm{~S}$ & $\mathrm{AR}$ \\
\hline Trichorhinophalageal syndrome 1 & TRPS1 & FISH & $\mathrm{AD}$ \\
\hline
\end{tabular}

${ }^{a}$ Testing not available in the United States at the time of manuscript preparation.

$\mathrm{A}$, analyte (biochemical); AD, autosomal dominant; AR, autosomal recessive; Arr, array comparative genomic hybridization; Del/Dup, deletion/duplication analysis; E, enzyme assay; FISH, fluorescence in situ hybridization; S, gene sequencing; Sp, sporadic; TM, targeted mutation analysis; XLD, X-linked dominant; XLR, X-linked recessive. 
Table 4. Short stature and other anomalies

\begin{tabular}{|c|c|c|c|}
\hline $\begin{array}{l}\text { Short stature }+ \\
\text { other anomalies }\end{array}$ & Gene/locus & Technique & Inheritance \\
\hline Aarskog syndrome & $F G D 1$ & $\mathrm{~S}$ & XLR \\
\hline Bloom syndrome & RECQL3 & Cyt, S, $\mathrm{TM}^{a}$ & $\mathrm{AR}$ \\
\hline Cockayne syndrome & ERCC6, ERCC8 & $\mathrm{S}$ & $\mathrm{AR}$ \\
\hline Coffin-Lowry & $\begin{array}{r}R P S 6 K A 3 \\
(R S K 2)\end{array}$ & S, Del/Dup & XLD \\
\hline \multirow{3}{*}{$\begin{array}{l}\text { Cornelia de Lange } \\
\text { syndrome }\end{array}$} & NIPBL & $\mathrm{S}$ & $\mathrm{AD}, \mathrm{Sp}$ \\
\hline & SMC1L1 & S & XLR \\
\hline & $S M C 3^{a}$ & & $\mathrm{AD}, \mathrm{Sp}$ \\
\hline Dubowitz syndrome & Unknown & & $\mathrm{AR}$ \\
\hline $\begin{array}{l}\text { Floating Harbor } \\
\text { syndrome }\end{array}$ & Unknown & & $\mathrm{AD}, \mathrm{Sp}$ \\
\hline Kabuki syndrome & Unknown & & $\mathrm{AD}, \mathrm{Sp}$ \\
\hline $\begin{array}{l}\text { Langer-Geidion } \\
\text { syndrome }\end{array}$ & $8 \mathrm{q} 24.11-\mathrm{q} 24.13$ & Cyt, FISH & $\mathrm{AD}$ \\
\hline $3 \mathrm{M}$ syndrome & $C U L 7^{a}$ & & $\mathrm{AR}$ \\
\hline Mulibrey nanism & TRIM3 $7^{a}$ & & $\mathrm{AR}$ \\
\hline $\begin{array}{l}\text { Nijmegan breakage } \\
\text { syndrome }\end{array}$ & $N B S 1$ & $\mathrm{TM}$ & $\mathrm{AR}$ \\
\hline Noonan syndrome & $\begin{array}{l}\text { PTPN11, RAF1, } \\
\text { KRAS, SOS1 }\end{array}$ & $\mathrm{S}$ & $\mathrm{AD}$ \\
\hline $\begin{array}{l}\text { Prader-Willi } \\
\text { syndrome }\end{array}$ & $15 q 11-q 13$ & $\begin{array}{l}\text { FISH, } \\
\text { Methyl, } \\
\text { UPD }\end{array}$ & $\mathrm{Sp}$ \\
\hline \multirow[t]{2}{*}{ Robinow syndrome } & $R O R 2$ & $\mathrm{~S}$ & $\mathrm{AR}$ \\
\hline & Unknown & & $\mathrm{AD}$ \\
\hline $\begin{array}{l}\text { Rubinstein-Taybi } \\
\text { syndrome }\end{array}$ & $\begin{array}{l}\text { 16p13.3, } \\
\text { CREBBP, } \\
\text { EP300 }\end{array}$ & FISH, S & $\mathrm{AD}, \mathrm{Sp}$ \\
\hline $\begin{array}{l}\text { Russell-Silver } \\
\text { syndrome }\end{array}$ & $\begin{array}{l}\text { UPD 7, H19, } \\
\text { others }^{a}\end{array}$ & $\begin{array}{l}\text { UPD, } \\
\text { Methyl }\end{array}$ & $\mathrm{Sp}$ \\
\hline $\begin{array}{l}\text { Schimke } \\
\text { immunoosseous } \\
\text { dysplasia }\end{array}$ & $S M A R C A L 1^{a}$ & & $\mathrm{AR}$ \\
\hline SHORT syndrome & Unknown & & $\mathrm{AD}$ \\
\hline $\begin{array}{l}\text { SHOX-related short } \\
\text { stature }\end{array}$ & Xp22.3 & Cyt, FISH, S & XLD \\
\hline $\begin{array}{l}\text { Smith-Magenis } \\
\text { syndrome }\end{array}$ & $17 \mathrm{p} 11.2 / R A I 1$ & Cyt, FISH, S & $\mathrm{Sp}$ \\
\hline Turner syndrome & $\mathrm{Xp}$ & Cyt & $\mathrm{Sp}$ \\
\hline $\begin{array}{l}\text { Velocardiofacial/ } \\
\text { DiGeorge }\end{array}$ & $\begin{array}{l}22 \mathrm{q} 11.2 \\
\quad 10 \mathrm{p} 14-13\end{array}$ & $\begin{array}{l}\text { Cyt, FISH, } \\
\text { Del/Dup }\end{array}$ & $\mathrm{AD}, \mathrm{Sp}$ \\
\hline Williams syndrome & $7 q 11.23$ & FISH & $\mathrm{AD}, \mathrm{Sp}$ \\
\hline $\begin{array}{l}\text { XLMR-hypotonic } \\
\text { facies }\end{array}$ & $A T R X$ & $\begin{array}{l}\text { S, TM, } \\
\text { Del/Dup }\end{array}$ & XLR \\
\hline
\end{tabular}

${ }^{a}$ Testing not available in the United States at the time of manuscript preparation. Cyt, cytogenetic analysis; AD, autosomal dominant; AR, autosomal recessive; Del/Dup, deletion/duplication analysis; FISH, fluorescence in situ hybridization; S, gene sequencing; Sp, sporadic; TM, targeted mutation analysis; XLD, X-linked dominant; XLR, X-linked recessive.
Table 5. Selected IUGR syndromes

\begin{tabular}{|c|c|c|c|}
\hline $\begin{array}{l}\text { Selected IUGR } \\
\text { syndromes }\end{array}$ & Gene & Technique & Inheritance \\
\hline Bloom syndrome & $R E C Q L 3$ & Cyt, TM & $\mathrm{AR}$ \\
\hline Cockayne syndrome & $\begin{array}{l}\text { ERCC6, } \\
\text { ERCC } 8\end{array}$ & $\mathrm{~S}$ & $\mathrm{AR}$ \\
\hline Donohue syndrome & $I N S R^{a}$ & & $\mathrm{AR}$ \\
\hline Dubowitz syndrome & Unknown & & $\mathrm{AR}$ \\
\hline $\begin{array}{l}\text { Laron syndrome/ } \\
\text { CPD }\end{array}$ & GHR & $\mathrm{S}$ & $\mathrm{AR}$ \\
\hline $\begin{array}{l}\text { Insulin-like growth } \\
\text { factor } 1 \text { deficiency }\end{array}$ & $I G F 1^{a}$ & & $\mathrm{AR}$ \\
\hline $\begin{array}{l}\text { Insulin-like growth } \\
\text { factor } 1 \text { resistance }\end{array}$ & $I G F I R^{a}$ & & $\mathrm{AD}, \mathrm{AR}$ \\
\hline $\begin{array}{l}\text { Kenny-Caffey } \\
\text { syndrome }\end{array}$ & $T B C E^{a}$ & & $\mathrm{AR}$ \\
\hline $\begin{array}{l}\text { Nijmegan breakage } \\
\text { syndrome }\end{array}$ & $N B S 1$ & $\mathrm{TM}$ & $\mathrm{AR}$ \\
\hline $\begin{array}{l}\text { Russell-Silver } \\
\text { syndrome }\end{array}$ & $\begin{array}{l}\text { UPD 7, H19, } \\
\text { others }^{a}\end{array}$ & UPD, Methyl & $\mathrm{Sp}$ \\
\hline $\begin{array}{l}\text { Schimke } \\
\text { immunoosseous } \\
\text { dysplasia }\end{array}$ & SMARCAL $1^{a}$ & & $\mathrm{AR}$ \\
\hline $\begin{array}{l}\text { Smith-Lemli-Opitz } \\
\text { syndrome }\end{array}$ & DHCR7 & $\mathrm{A}, \mathrm{S}, \mathrm{TM}$ & $\mathrm{AR}$ \\
\hline \multicolumn{4}{|c|}{$\begin{array}{l}\text { Testing for these other causes not available in the United States at the time of } \\
\text { manuscript preparation. } \\
\text { A, analyte (biochemical); AD, autosomal dominant; AR, autosomal recessive; } \\
\text { Cyt, cytogenetic analysis; Methyl, methylation; S, gene sequencing; TM, targeted } \\
\text { mutation analysis; UPD, uniparental disomy. }\end{array}$} \\
\hline
\end{tabular}

Table 6. Evaluation of IUGR

Maternal health history

Teratogen history

Pregnancy history

Placental pathology

High resolution chromosome analysis and/or array CGH

Ophthalmologic evaluation

Hearing screen

Evaluation for congenital infection (titers, culture, PCR)

Bone dysplasia survey

Endocrine evaluation with history of persistent hypoglycemia

Cranial imaging of pituitary if endocrine abnormality

If physical examination reveals proportionate short stature, a detailed physical examination may reveal signs that are consistent with a recognizable genetic syndrome. Molecular genetic testing is available for confirmation of some of these conditions 
(Table 4). If physical examination does not suggest a recognizable syndrome, then chromosome analysis should be performed, which has the added advantage of addressing the potential of mosaicism. If this analysis is negative, genomic array studies may be considered to evaluate for changes in genome copy number.

For the children with intrauterine onset of short stature, the approach is similar to that of the older child with short stature. Comparison should be made of the infant's birth weight, birth length and birth head circumference, body proportions, and documentation of major and minor anomalies. Depending on the age at which the SGA infant is being evaluated, assessment of the postnatal growth pattern will also yield clues to the underlying etiology. Selected syndromes associated with IUGR for which the genetic basis is known are presented in Table 5. Testing useful in the evaluation of infant with prenatal onset growth deficiency is presented in Table 6 .

If no diagnosis is apparent after initial clinical evaluation and appropriate laboratory or radiographic studies, periodic reassessment is indicated. The timing of reassessment will depend on the child's age, whether or not there are other significant developmental or physical features present, the family's interest or anxiety, and changes in the family history. A specific diagnosis may become apparent or the differential diagnoses altered with evolution of the phenotype and additional family history that may become available. Furthermore, new diagnostic tests and techniques may allow diagnosis or confirmation of a clinical diagnosis in the future.

\section{REFERENCES}

1. Lam WFF, Hau WLK, Lam TS. Evaluation of referrals for genetic investigation of short stature in Hong Kong. Chin Med $J$ 2002;115:607-611.

2. Hall BD. A diagnostic approach to genetic causes of short stature. Ala J Med Sci 1985;22:431-435.

3. Kant SG, Wit JM, Breuning MH. Genetic analysis of short stature. Horm Res 2003;60:157-165.

4. Vogiatzi MG, Copeland KC. The short child. Pediatr Rev 1998;19:92-99.

5. Lee PA, Chernausek SD, Hokken-Koelega AC, Czernichow P. International Small for Gestational Age Advisory Board consensus development conference statement: management of short children born small for gestational age, April 24-October 1, 2001. Pediatrics 2003;111:1253-1261.

6. Huber C, Rosilio M, Munnich A, Cormier-Daire V, French SHOX GeNeSIS Module. High incidence of SHOX anomalies in individuals with short stature. $J$ Med Genet 2006;43:735-739.

7. Jorge AA, Souza SC, Nishi MY, et al. SHOX mutations in idiopathic short stature and Leri-Weill dyschondrosteosis: frequency and phenotypic variability. Clin Endocrinol (Oxf) 2007;66:130-135. 